\title{
HUBUNGAN PEMBERIAN ASI EKSKLUSIF DAN BAYI BERAT LAHIR RENDAH (BBLR) DENGAN KEJADIAN PNEUMONIA PADA BALITA DI WILAYAH PUSKESMAS KAMONJI
}

\author{
Linda ${ }^{1 \mathrm{~K}}$ \\ ${ }^{1}$ Prodi DIII Jurusan Kebidanan Poltekkes Kemenkes Palu \\ email Penulis Korespondensi $\left({ }^{\mathrm{K}}\right)$ : caemlin@ymail.com
}

\begin{abstract}
Pneumonia is the premiere killer of toddlers in the world and in Indonesia. In Indonesia pneumonia is the cause of $15 \%$ of infant mortality is estimated as many as 922,000 under-fives in 2015. Puskesmas Kamonji is a health center that has the highest number of pneumonia cases in the city of Palu is 422 cases in 2015. Based on evidence that the risk factor of pneumonia is the lack of breastfeeding exclusive, malnutrition, indoor air pollution, low birth weight (LBW), population density, and lack of measles immunization. The purpose of this study is known factors associated with the incidence of pneumonia, namely Exclusive breastfeeding and history of low birth weight (LBW). The type of research used is analytical survey with case control approach. The samples in this study were all mothers who had children under 12-59 months in the Kamonji Puskemas Working Area consisted of 70 samples consisting of 35 case samples and 35 control samples. This research uses Chi-square statistical analysis with $5 \%$ error rate $(\alpha$ $=0,05)$ and trust level $95 \%$. The results showed that exclusive breastfeeding $(\mathrm{P}$ value $=0.147)$ and low birth weight $(\mathrm{P}$ Value $=1,000)$ did not correlate with pneumonia occurrence in children aged 12-59 months. The conclusion in this study was no association between exclusive breastfeeding and the incidence of pneumonia and no association between low birth weight infants and the incidence of pneumonia. Suggestions for Health Officers to continue to give counseling about the importance of healthy living behavior teaches the community how important to wash hands with soap and keep the nutritional status of toddlers is always good.
\end{abstract}

Keywords: Exclusive Breast Milk, Low birth weight, Pneumonia

\section{PENDAHULUAN}

\section{Latar Belakang}

Berdasarkan data dari World Health Organization (WHO), diperkirakan 130 juta bayi dilahirkan di Dunia setiap tahun dan 4 juta bayi meninggal dalam 28 hari pertama kehidupannya. Kematian bayi berkontribusi $40 \%$ dari total kematian balita di seluruh Dunia dan 67\% kematian bayi di Dunia terjadi di sepuluh Negara, terutama di Afrika dan Asia. Penyebab utama kematian bayi di seluruh Dunia adalah infeksi terutama sepsis, tetanus, diare, premature, asfiksia, dan pneumonia ${ }^{(1)}$.

Pneumonia adalah infeksi akut yang mengenai jaringan paru-paru (alveoli) yang dapat disebabkan oleh berbagai mikroorganisme seperti virus, jamur, dan bakteri. Gejala penyakit pneumonia yaitu menggigil, demam, sakit kepala, batuk, mengeluarkan dahak, dan sesak napas ${ }^{(2)}$. Pneumonia adalah pembunuh utama balita di Dunia dan di Indonesia. Di Dunia setiap tahun diperkirakan lebih dari 2 juta balita meninggal karena pneumonia (1 balita/20 detik) dari 9 juta total kematian balita. Diantara 5 kematian balita, 1 diantaranya disebabkan 
oleh pneumonia ${ }^{(3)}$. Di Indonesia pneumonia merupakan penyebab dari 15\% kematian balita yaitu diperkirakan sebanyak 922.000 balita di tahun $2015^{(2)}$.

Kelompok umur penduduk, Period prevalence pneumonia yang tinggi terjadi pada kelompok umur 1-4 tahun. Period prevalence pneumonia balita di Indonesia adalah 18,5\%. Balita pneumonia yang berobat hanya $1,6 \%$. Insidens tertinggi pneumonia balita terdapat pada kelompok umur $12-23$ bulan $(21,7 \%)^{(4)}$.

Berdasarkan laporan seksi Pemberantasan Penyakit Menular (P2M) Dinas Kesehatan Kota Palu, jumlah penderita pneumonia pada Tahun 2014 adalah 4.403 penderita, mengalami penurunan sebesar 6,9\% dibandingkan cakupan Tahun 2013 (4.709 penderita), dan sebanyak 4.050 penderita (laki-laki 2.193, perempuan 1.857 ) atau $91,98 \%$ terjadi pada balita, sisanya sebesar 353 kasus $(8,02 \%)$ terjadi pada golongan umur $\geq 5$ tahun ${ }^{(5)}$.

Data Dinas Kesehatan Kota Palu menunjukkan bahwa dari 12 Puskesmas di Kota Palu jumlah kasus pneumonia pada balita yang tertinggi terdapat di Puskesmas Kamonji yaitu sebanyak 422 kasus (202 kasus pada laki-laki dan 220 kasus pada perempuan) sedangkan jumlah kasus pneumonia pada balita yang terendah terdapat di Puskesmas Mamboro yaitu sebanyak 65 kasus (31 kasus pada laki-laki dan 34 kasus pada perempuan) ${ }^{(6)}$.

Berdasarkan bukti bahwa faktor risiko pneumonia adalah kurangnya pemberian ASI eksklusif, gizi buruk, polusi udara dalam ruangan (indor air pollution), bayi berat lahir rendah (BBLR), kepadatan penduduk, dan kurangnya imunisasi campak ${ }^{(3)}$.

Hasil penelitian Kusmilarsih tahun $2015^{(7)}$ menunjukkan bahwa ada hubungan berat badan lahir dan pemberian ASI Eksklusif dengan kejadian pneumonia pada balita. Dari penelitian ini balita yang tidak diberikan ASI Eksklusif lebih banyak yang menderita pneumonia dari pada balita yang diberikan ASI Eksklusif, hal ini dikarenakan kekebalan tubuh anak balita tergantung pada pemberian ASI Eksklusif, oleh karena itu ASI Eksklusif sangat penting karena peluang untuk terkena penyakit terutama pneumonia lebih kecil dibandingkan dengan anak yang tidak ASI Eksklusif.

Hasil penelitian Arminingrum tahun $2016^{\left({ }^{(8)}\right.}$ bahwa balita yang mempunyai riwayat bayi berat lahir rendah (BBLR) lebih banyak yang mengalami pneumonia. Bayi dengan berat badan lahir rendah (BBLR) mempunyai risiko kematian yang lebih besar dibanding dengan berat badan lahir normal, terutama pada bulan-bulan pertama kelahiran karena pembentukan zat anti kekebalan kurang sempurna dan BBLR menunjukkan belum sempurnanya fungsi organ tubuh dengan keadaannya yang lemah sehingga lebih mudah terkena penyakit infeksi, terutama pneumonia dan infeksi saluran pernapasan lainnya.

Survei yang dilakukan di Puskesmas Kamonji, pada 3 bulan terakhir yaitu pada bulan September, Oktober dan November terdapat 46 kasus pneumonia pada balita (23 kasus pada laki-laki dan 23 kasus pada perempuan) ${ }^{(9)}$.

\section{Tujuan}

Tujuan penelitian ini adalah mengetahu faktor yang berhubungan dengan kejadian pneumonia, yaitu pemberian ASI Eksklusif dan riwayat berat badan lahir rendah (BBLR).

\section{METODE PENELITIAN}

Jenis penelitian adalah Survei Analitik dengan pendekatan Case Control atau Kasus Kontrol Penelitian dilaksanakan pada tanggal 8 April-31 Mei 2017 dan tempat penelitian di Wilayah Kerja Puskesmas Kamonji. Populasi pada penelitian ini adalah semua ibu yang mempunyai balita berumur 12-59 bulan dan berada di Wilayah Kerja Puskesmas Kamonji pada tiga bulan terakhir yaitu bulan Januari, Februari dan Maret 2017 sebanyak 70 balita. Pengambilan sampel semua ibu yang mempunyai balita berumur 12-59 bulan, menderita

28 | Penerbit: Jurusan Kebidanan, Poltekkes Kemenkes Palu 
pneumonia dan berada di wilayah kerja Puskesmas Kamonji pada tiga bulan terakhir yaitu bulan Januari, Februari dan Maret 2017 sebanyak 35 balita sebagai kasus ditambah 35 balita sebagai kontrol yaitu balita yang ada di Wilayah Kerja Puskesmas Kamonji yang tidak menderita pneumonia tetapi mempunyai karakteristik yang hampir sama dengan kelompok kasus. Teknik pengumpulan data yaitu data primer diperoleh dari lapangan dengan mengadakan observasi dan wawancara langsung kepada responden dengan menggunakan daftar pertanyaan (Questionare). Data Sekunder dalam penelitian ini diperoleh dari berbagai literaturdan instansi-instansi pemerintah yang terkait dengan kegiatan penelitian seperti data dari Dinas Kesehatan Provinsi Sulawesi Tengah, Dinas Kesehatan Kota Palu dan Puskesmas Kamonji.

\section{HASIL PENELITIAN}

Penelitian ini dilaksanakan pada tanggal 8 April- 31 Mei 2017 di Wilayah Kerja Puskesmas kamonji. Jenis penelitian ini merupakan penelitian analitik dengan pendekatan case control. Jumlah sampel dalam penelitian ini 70 sampel yang terdiri dari 35 sampel kasus dan 35 sampel kontrol yang dihitung dari bulan Januari sampai Maret 2017. Pengumpulan data dilakukan dengan menggunakan kuisioner dengan cara turun langsung kerumah responden dan melakukan wawancara dapat dilihat pada tabel 1 berikut ini :

Tabel 1.

Distribusi Frekuensi Berdasarkan Pemberian ASI Eksklusif pada Balita di Wilayah Kerja Puskesmas Kamonji Tahun 2017

\begin{tabular}{ccc}
\hline Pemberian ASI & Frekuensi & Presentase \\
\hline ASI Eksklusif & 30 & $42,9 \%$ \\
Tidak ASI Eksklusif & 40 & $57,1 \%$ \\
\hline Total & 70 & $100 \%$ \\
\hline
\end{tabular}

Berdasarkan tabel 1 menunjukkan bahwa diperoleh gambaran bahwa balita yang mendapatkan ASI Eksklusif ada 30 balita (42,9\%), dan yang tidak mendapatkan ASI Eksklusif ada 40 balita (57,1\%).

Tabel 2.

Distribusi Frekuensi Berdasarkan bayi berat lahir rendah(BBLR) pada Balita di Wilayah Kerja Puskesmas Kamonji Tahun 2017

\begin{tabular}{ccc}
\hline BBLR & Frekuensi & Presentase \\
\hline BBLR & 12 & $17,1 \%$ \\
Tidak BBLR & 58 & $82,9 \%$ \\
\hline Total & 70 & $100 \%$ \\
\hline
\end{tabular}

Berdasarkan tabel 2 menunjukkan bahwa diperoleh gambaran bahwa balita yang mengalami bayi berat lahir rendah (BBLR) ada 12 balita $(17,1 \%)$, dan yang tidak mengalami bayi berat lahir rendah (BBLR) ada 58 balita $(82,9 \%)$.

Tabel 3.

Distribusi Frekuensi Kejadian Pneumonia pada Balita di Wilayah Kerja Puskesmas Kamonji Tahun 2017

\begin{tabular}{ccc}
\hline Pneumonia & Frekuensi & Presentase \\
\hline Pneumonia & 35 & $50 \%$ \\
Tidak Pneumonia & 35 & $50 \%$ \\
\hline Total & 70 & $100 \%$ \\
\hline
\end{tabular}

29 | Penerbit: Jurusan Kebidanan, Poltekkes Kemenkes Palu 
Berdasarkan tabel 3 menunjukkan bahwa diperoleh diperoleh gambaran bahwa dari 70 sampel yang diambil, balita yang mengalami pneumonia ada 35 balita $(50 \%)$, dan balita yang tidak mengalami pneumonia ada 35 balita $(50 \%)$.

Tabel 4.

Hubungan Pemberian ASI Eksklusif dengan Kejadian Pneumonia pada Balita di Wilayah Kerja Puskesmas Kamonji Tahun 2017

\begin{tabular}{ccccccccc}
\hline & \multicolumn{3}{c}{ Kejadian pneumonia } & & & \\
\cline { 2 - 5 } Pemberian ASI & $\begin{array}{c}\text { Tidak } \\
\text { Pneumonia }\end{array}$ & \multicolumn{2}{c}{ Pneumonia } & & Total & $\begin{array}{c}\text { P } \\
\text { value }\end{array}$ & (OR) CI=95\% \\
\cline { 2 - 5 } & $\mathrm{F}$ & $\%$ & $\mathrm{~F}$ & $\%$ & & & \\
\hline ASI Eksklusif & 18 & 25,7 & 12 & 17,1 & 30 & & 0,493 \\
$\begin{array}{c}\text { Tidak ASI } \\
\text { Eksklusif }\end{array}$ & 17 & 24,3 & 23 & 32,9 & 40 & & $(0,188-1.20)$ \\
\hline Total & 35 & 50 & 35 & 50 & 70 & & \\
\hline
\end{tabular}

Berdasarkan tabel 4, dari 70 sampel balita yang tidak menderita pneumonia tetapi diberi ASI Eksklusif ada 18 balita $(25,7 \%)$ dan balita yang tidak menderita Pneumonia tetapi tidak diberi ASI Eksklusif ada 17 balita (24,3\%) sedangkan balita yang menderita pneumonia tetapidiberi ASI Eksklusif ada 12 balita $(17,1 \%)$ dan balita yang menderita pneumonia tetapi tidak diberi ASI Eksklusif ada 23 balita (32,9\%).

Berdasarkan hasil uji statistik dengan tingkat kesalahan 5\% diperoleh P Value $=0,147$ $(0.147>0,05)$ dan nilai Odds Ratio $(\mathrm{OR})=0,493$ dengan interval kepercayaan $(\mathrm{CI}) 95 \%$ yaitu $(0,188-1.20)$ artinya Ha ditolak dan Ho diterima dengan interpretasi tidak ada hubungan yang signifikan antara pemberian ASI Eksklusif dengan kejadian pneumonia.

Tabel 5.

Hubungan bayi berat lahir rendah(BBLR) dengan Kejadian

Pneumonia pada Balita di Wilayah Kerja Puskesmas Kamonji Tahun 2017

\begin{tabular}{|c|c|c|c|c|c|c|c|}
\hline \multirow{3}{*}{ BBLR } & \multicolumn{4}{|c|}{ Kejadian pneumonia } & \multirow{3}{*}{ Total } & \multirow{3}{*}{$\begin{array}{c}\mathrm{P} \\
\text { value }\end{array}$} & \multirow{3}{*}{$(\mathrm{OR}) \mathrm{CI}=95 \%$} \\
\hline & \multicolumn{2}{|c|}{$\begin{array}{c}\text { Tidak } \\
\text { Pneumonia }\end{array}$} & \multicolumn{2}{|c|}{ Pneumonia } & & & \\
\hline & $\mathrm{F}$ & $\%$ & $\mathrm{~F}$ & $\%$ & & & \\
\hline BBLR & 6 & 8,7 & 6 & 8,7 & 12 & & 1,000 \\
\hline $\begin{array}{l}\text { Tidak } \\
\text { BBLR }\end{array}$ & 29 & 41,3 & 29 & 41,3 & 58 & 1,000 & $(0,288-3,467)$ \\
\hline Total & 35 & 50 & 35 & 50 & 70 & & \\
\hline
\end{tabular}

30 | Penerbit: Jurusan Kebidanan, Poltekkes Kemenkes Palu 
Berdasarkan tabel 5 dari 70 sampel balita yang tidak menderita pneumonia tetapi BBLR ada 6 balita $(8,7 \%)$ dan balita yang tidak menderita pneumonia tetapi tidak BBLR ada 29 balita $(41,3 \%)$ sedangkan balita yang menderitapneumonia tetapi BBLR ada 6 balita $(8,7 \%)$ dan balita yang menderita pneumonia tetapi tidak BBLR ada 29 balita $(41,3 \%)$.

Berdasarkan hasil uji statistik dengan tingkat kesalahan 5\% diperoleh $\mathrm{P}$ Value $=1,000$ $(1,000>0,05)$ dan nilai Odds Ratio $(\mathrm{OR})=1,000$ dengan interval kepercayaan (CI) 95\% yaitu $(0,288-3,467)$ artinya Ha ditolak dan Ho diterima dengan interpretasi tidak ada hubungan yang signifikan antara bayi berat lahir rendah(BBLR) dengan kejadian pneumonia.

\section{PEMBAHASAN}

Hasil penelitian ini secara statistik dapat disimpulkan bahwa tidak terdapat hubungan yang signifikan antara pemberian ASI Eksklusif dengan kejadian pneumonia. Pada penelitian ini baik kelompok kasus maupun kelompok kontrol pada umumnya tidak memberikan ASI Eksklusif, sehingga tidak di dapatkan hubungan yang bermakna antara pemberian ASI Eksklusif dengan kejadian Pneumonia pada balita di wilayah kerja Puskesmas Kamonji. Hasil penelitian ini sejalan dengan penelitian sebelumnya yang dilakukan oleh Yulia tahun $2016^{(10)}$ di Padang menunjukkan bahwa tidak terdapat hubungan yang bermakna antara pemberian ASI Eksklusif dengan kejadian pneumonia. Meskipun balita tidak mendapatkan ASI Eksklusif, hal tersebut bukan menjadi faktor penyebab terjadinya pneumonia.

Penelitian ini tidak sejalan dengan penelitian yang dilakukan Widayat tahun $2014{ }^{(11)} \mathrm{di}$ Wilayah Puskesmas Mojogedang II Kabupaten Karang Anyar menunjukkan bahwa terdapat hubungan yang bermakna antara pemberian ASI Eksklusif dengan kejadian Pneumonia pada balita.

Menurut peneliti ada faktor lain yang dapat menyebabkan pneumonia seperti keadaan status gizi, dimana status gizi yang kurang dapat menyebabkan sistem kekebalan tubuh balita mudah terserang penyakit seperti infeksi, karena semakin baik status gizi maka akan semakin baik pula sistem kekebalan tubuh. Hal tersebut sejalan dengan pendapat yang dikemukakan oleh Williams tahun $2014^{(12)}$ bahwa asupan gizi yang kurang merupakan risiko untuk kejadian dan kematian balita dengan infeksi saluran pernapasan.

Selain itu, sekarang sudah ada program pemerintah yaitu pemberian suplementasi vitamin A pada balita umur 6-59 bulan. Dimana Vitamin A dapat bermanfaat untuk meningkatkan imunitas dan melindungi saluran pernapasan dari infeksi kuman sehingga hal tersebut dapat menjaga daya tahan tubuh balita meskipun tidak mendapatkan ASI secara Eksklusif.

Hasil penelitian ini tidak sejalan dengan teori yang dikemukakan oleh Williams tahun $2014{ }^{(12)}$ bahwa ASI merupakan makanan alami terbaik bagi bayi. Selain komposisinya yang mampu memenuhi kebutuhan gizi bayi hingga usia 6 bulan pertama (ASI Eksklusif), kandungan kolostrum yang dimiliki ASI dipercaya memberikan proteksi terhadap saluran nafas terutama pneumonia. Bayi yang diberi ASI eksklusif akan lebih sehat dan jarang sakit di bandingkan dengan bayi yang tidak mendapat ASI Eksklusif, terutama berperan penting dalam menurunkan angka kesakitan (morbiditas) bahkan kematian (mortalitas) pada bayi.

Hasil penelitian hubungan bayi berat lahir rendah (BBLR)dengan kejadian pneumonia dengan menggunakan uji statistik diperoleh $(\mathrm{P}$ Valeue $=1,000)$ yang artinya tidak terdapat hubungan yang signifikan antara bayi berat lahir rendah (BBLR) dengan kejadian pneumonia. Dimana bayi berat lahir rendah (BBLR) pada balita bukan penyebab langsung terjadinya pneumonia.

Hasil penelitian ini tidak sejalan dengan penelitian yang dilakukan oleh Arminingrum tahun $2016^{(8)}$ menunjukkan hubungan yang bermakna antara riwayat bayi berat lahir rendah (BBLR) dengan kejadian Pneumonia pada Balita. Dimana dalam penelitian tersebut bayi 
dengan berat badan lahir rendah (BBLR) mempunyai resiko yang lebih besar di banding dengan berat badan lahir normal.

Menurut peneliti ada faktor lain yang dapat mempengaruhi terjadinya pneumonia pada balita seperti kelengkapan pemberian imunisasi dasar lengkap, dimana pemberian imunisasi dasar lengkap tersebut dapat menambah daya imun balita menjadi lebih kuat. Sehingga balita mendapat perlindungan yang kuat dari imunisasi tersebut untuk mencegah terjadinya serangan penyakit infeksi seperti pneumonia. Hal tersebut sejalan dengan penelitian sebelumnya yang dilakukan Ardin tahun $2015^{(13)}$ bahwa terdapat hubungan yang signifikan antara pemberian imunisasi dasar dengan kejadian Pneumonia.

Hasil penelitian ini tidak sejalan dengan teori yang dikemukakan oleh Williams tahun $2014^{(13)}$ bahwa bayi berat lahir rendah (BBLR) menentukan pertumbuhan dan perkembangan fisik dan mental pada masa Balita. Bayi dengan bayi berat lahir rendah (BBLR) mempunyai risiko kematian yang lebih besar dibandingkan dengan bayi dengan berat lahir normal terutama pada bulan bulan pertama kelahiran karena pembentukan zat kekebalan kurang sempurna sehingga lebih mudah terkena penyakit infeksi terutama pneumonia dan infeksi saluran pernafasan lainnya. Bayi dengan bayi berat lahir rendah (BBLR) menunjukkan kecendrungan untuk lebih rentan menderita penyakit infeksi dibandingkan bayi dengan berat badan lahir normal, hal tersebut merupakan penyebab tingginya angka kematian bayi.

Hasil penelitian ini sejalan dengan penelitian Yulia tahun $2016^{(10)}$ mendapatkan hubungan yang tidak bermakna antara bayi berat lahir rendah (BBLR) dengan kejadian Pneumonia. Berdasarkan hasil penelitian ini ditemukan bahwa riwayat bayi berat lahir rendah (BBLR) bukan merupakan faktor resiko terjadinya Pneumonia. Hal ini disebabkan pada kelompok kasus maupun kontrol sebagian besar $>82,9 \%$ sama-sama tidak ada riwayat bayi berat lahir rendah (BBLR), sehingga tidak didapatkan hubungan yang bermakna antara riwayat bayi berat lahir rendah (BBLR) dengan kejadian pneumonia. Pada saat ini penanganan dan perawatan bayi dengan bayi berat lahir rendah (BBLR) sudah semakin baik sehingga dapat mengurangi angka kesakitan dan kematian akibat BBLR.

\section{SIMPULAN DAN SARAN}

Berdasarkan hasil penelitian ini maka dapat disimpulkan bahwa Tidak terdapat hubungan yang bermakna antara pemberian ASI Eksklusif dengan kejadian Pneumonia pada balita umur 12-59 bulan di wilayah kerja Puskesmas Kamonji. Tidak terdapat hubungan yang bermakna antara bayi berat lahir rendah (BBLR) dengan kejadian Pneumonia pada balita umur 12-59 bulan di wilayah kerja Puskesmas Kamonji. Saran, Upaya yang dapat dilakukan adalah diharapkan kepada pihak Bagi Puskesmas Kamonji dan tenaga kesehatan kiranya dapat melakukan penyuluhan tentang pentingnya perilaku hidup bersih dan sehat seperti mengajarkan kepada masyarakat bagaimana mencuci tangan menggunakan sabun yang benar sebelum dan sesudah melakukan kegiatan terutama sebelum makan agar sistem kekebalan tubuh menjadi lebih terjaga dan dapat terhindar dari berbagai macam penyakit infeksi seperti pneumonia serta menjaga status gizi balita selalu baik dengan cara posyandu dan pemberian makanan tambahan.

\section{DAFTAR PUSTAKA}

1. Monika, FB. 2014. Buku Pintar ASI dan Menyusui. Jakarta: PT. Mizan Publika.

2. Dinas Kesehatan Indonesia. 2015. Profil Kesehatan Indonesia Tahun 2015. Indonesia.

3. Dinas Kesehatan Propinsi Sulawesi Tengah. 2014. Profil Kesehatan Propinsi Sulawesi Tengah Tahun 2014. Palu.

4. Riset Kesehatan Dasar. 2013. Indonesia. 
5. Dinas Kesehatan Kota Palu. 2015. Profil Kesehatan Kota Palu 2015. Palu.

6. Dinas Kesehatan Kota Palu. 2014. Profil Kesehatan Kota Palu 2014. Palu

7. Kusmilarsih, R. 2015. Hubungan berat badan lahir dan pemberian ASI eksklusif dengan kejadian pneumonia pada balita di puskesmas tawangsari kabupaten sukoharjo (online).

8. Arminingrum, F. 2016. Beberapa faktor yang berhubungan dengan kejadian pneumonia di wilayah kerja puskesmas bergas kabupaten semarang (online). (diakses pada 06 desember 2016).

9. Puskesmas Kamonji. 2016. Profil Kesehatan Puskesmas Kamonji Tahun 2015. UPTD Urusan Puskesmas Kamonji: Palu

10. Yulia. 2016. Faktor Risiko yang Berhubungan dengan Kejadian Pneumonia pada Balita di Kelurahan Air Tawar Barat Padang (Online). http://jurnal.fk.unand.ac.id.

11. Widayat. 2014. Faktor-Faktor Yang Berhubungan Dengan Pneumonia Pada Balita Di Wilayah Puskesmas Mojogedang II Kabupaten Karanganyar (Online).

12. Wiliams. 2014. Obstetri Wiliams. Jakarta: EGC.

13. Ardin, P. 2015. Hubungan Riwayat Pemberian ASI Tidak Eksklusif Dan Ketidak Lengkapan Imunisasi Difteri Pertusis Tetanus (Dpt) Dengan Pneumonia Anak Balita Di Puskesmas Wirobrajan Yogyakarta (online). 